\title{
Screening of Black Gram Genotypes against Major Pod Borers
}

\author{
Abhishek Yadav, Gaje Singh, Amit Yadav ${ }^{1}$, Hem Singh, Veer Singh², Pushpa Singh ${ }^{3}$
}

10.18805/LR-4686

\begin{abstract}
Background: Blackgram (Vigna mungo L.) is an important pulse crop occupying a unique position in Indian agriculture and it stands fourth in area and production among the pulses. The popularity of this pulse is due to its nutritional and industrial values. Blackgram crop is attacked by a number of insect pests from sowing to harvest in the field as well as in storage condition. Among these insectspests pod borers i.e. spotted pod borer, Maruca vitrata (Geyer) and gram pod borer, Helicoverpa armigera (Hubner) are serious insect-pests of black gram causing seed and pod damage. Therefore, keeping these views in mind, the present study was conducted. Methods: Present investigations were carried out during Kharif season of 2018 and 2019 to identify the resistant cultivars that are less susceptible to spotted pod borer and gram pod borer in black gram.

Result: Fifteen black gram genotypes were screened against pod borers i.e. M. vitrata and $H$. armigera. When the data of both years were pooled, the two genotypes viz., KU-99-05 and Azad Urd-1 were found with minimum pod infestation of 7.67 and 9.67 per cent, respectively and categorized as resistant $(\mathrm{R})$ against $M$. vitrata. The four genotypes KU-99-05, Azad Urd-1, Shekhar-2 and PU-6 were classified as resistant $(R)$ against $H$. armigera with minimum pod infestation of $5.83,6.17,8.50$ and 9.83 per cent, respectively during both the consecutive seasons (Kharif, 2018 and 2019).
\end{abstract}

Key words: Black gram, Genotypes, Helicoverpa armigera, Maruca vitrata, Pod damage, Screening.

\section{INTRODUCTION}

Pulses are an integral part of our diet and we consume them in a number of ways. The pulse crops are also important for the management of soil fertility due to their nitrogen fixation ability (Kantar et al., 2007). India is the largest pulse growing country in the world both in terms of area as well as production covering 46.87 per cent of area and 36.75 per cent of production (Anonymous, 2018). Therefore, more intensive interventions are required to increase the production and productivity of pulses in the country.

Black gram (Vigna mungo L.) is an important pulse crop occupying a unique position in Indian agriculture and it stands fourth in area and production among the pulses. The popularity of this pulse is due to its nutritional and industrial values (Nene, 2006).

Black gram is a rich source of protein $(24 \%)$, carbohydrate $(59.6 \%)$, fat $(1.4 \%)$, mineral $(3.2 \%)$ and fiber $(0.9 \%)$ (Tiwari and Shivhare, 2016). The major black gram producing states in India are Madhya Pradesh, Rajasthan, Uttar Pradesh Andhra Pradesh, Maharashtra and Tamil Nadu. In India, black gram is grown in 43.50 lakh ha $^{-1}$ with an annual production of 27.51 lakh tonnes and productivity of $632 \mathrm{~kg} \mathrm{ha}^{-1}$. In Uttar Pradesh, it occupies an area of 5.65 lakh ha-1 with production of 2.83 lakh tonnes and productivity of $501 \mathrm{~kg} \mathrm{ha}^{-1}$ (Anonymous, $2018 \mathrm{a}$ ).

Black gram crop is attacked by a number of insect pests from sowing to harvest in the field as well as in storage condition. Among these insect-pests pod borers i.e. spotted pod borer, Maruca vitrata (Geyer) and gram pod borer, Helicoverpa armigera (Hubner) are serious insect-pests of black gram causing seed and pod damage. Maruca vitrata is an important insect-pest of black gram appear on the crop
Department of Entomology, Sardar Vallabhbhai Patel University of Agriculture and Technology, Meerut-250 110, Uttar Pradesh, India. ${ }^{1}$ School of Agricultural Sciences, Raffles University, Neemrana-301 706, Rajasthan, India.

${ }^{2}$ Department of Entomology, Swami Keshwanand Rajasthan Agricultural University, Bikaner-334 006, Rajasthan, India.

${ }^{3}$ Department of Entomology, Dr. Rajendra Prasad Central Agricultural University, Samastipur-848 125, Bihar, India.

Corresponding Author: Abhishek Yadav, Department of Entomology, Sardar Vallabhbhai Patel University of Agriculture and Technology, Meerut-250 110, Uttar Pradesh, India.

Email: abhicoa2@gmail.com

How to cite this article: Yadav, A., Singh, G., Yadav, A., Singh, H., Singh, V. and Singh, P. (2021). Screening of Black Gram Genotypes against Major Pod Borers. Legume Research. DOI:10.18805/LR-4686.

Submitted: 05-06-2021 Accepted: 02-08-2021 Online:24-08-2021

from vegetative to reproductive stage and cause substantial damage to flowers, by webbing and also boring into the pods. The damage imposed by $H$. armigera is generally confined to flower heads, seeds and pods. The pod borers, $M$. vitrata and $H$. armigera is considered to be important in causing economic losses to the farmer (Reddy, 1998). Resistant varieties have their greatest value in crops protection of low vales per hectare or situations when the yield varies greatly due to uncertainties of weather or other insect-pest damage. Thus, blackgram is ideally suited for exploiting the resistance phenomenon to control $M$. vitrata and $H$. armigera ideally and economically. Therefore, keeping these views in mind, the present study was conducted to identify the resistant 
cultivars that are less susceptible to spotted pod borer and gram pod borer in black gram.

\section{MATERIALS AND METHODS}

The field experiment was conducted at CRC of SVPUA and T, Meerut to screen 15 black gram genotypes during Kharif, 2018 and 2019 under natural infestation conditions against $M$. vitrata and $H$. armigera. Each genotype was sown in 2 row of 4-meter lengths each with inter and intra row spacing of $30 \times 10 \mathrm{~cm}$, respectively. A total of three replications were maintained. The sowing of varieties was done on $18^{\text {th }}$, August 2018 and $20^{\text {th }}$, August 2019 during the first and second year, respectively. The data were recorded at the maturity of the crop from a hundred randomly selected pods of ten plants in each plot. Per cent pod damage was calculated by using the following formula.

Per cent pod damage $=$

$$
\frac{\text { Total number of damaged pods }}{\text { Total number of pods }} \times 100
$$

The entries were categorized into resistant, moderately resistant, moderately susceptible and susceptible based on pod borer infestation as mentioned in Table 1 (Krishna et al., 2006).

\section{RESULTS AND DISCUSSION}

Screening of black gram genotypes against $M$. vitrata during Kharif, 2018

The 15 black gram genotypes were screened against $M$. vitrata during Kharif, 2018. The statistically analyzed data (Table 2) reveals that the pod infestation by $M$. vitrata ranged from 8.67 to 28.67 per cent. Among all the black gram genotypes minimum pod infestation of 8.67 per cent was recorded in KU-99-05 and followed by Azad Urd-1 with 10.33 per cent pod infestation and categorized as resistant (R). Whereas, nine genotypes viz.,Shekhar-2, PU-6, PU-19, Azad Urd-2, KU-96-7, PU-35, PU-40, KU-302 and Shekhar1 were observed with pod infestation of $13.67,14.67,15.00$, $16.33,17.00,17.00,19.33,21.00$ and 22.33 per cent, respectively and these genotypes were found to be moderately resistant (MR) against $M$. vitrata. However four genotypes viz., PU-30 (25.67\%), Azad Urd-3 (26.67\%), KU$719(27.33 \%)$ and $\mathrm{KU}-88-9-1(28.67 \%)$ were found moderately susceptible (MS) against $M$. vitrata. Among all the 15 genotypes of black gram no genotype was found

Table 1: Classification of entries based on per cent pod damage (Krishna et al. 2006).

\begin{tabular}{lc}
\hline Pod damage (\%) & Category \\
\hline $1-12$ & resistant \\
$13-24$ & Moderately resistant \\
$25-30$ & Moderately susceptible \\
$>30$ & Susceptible \\
\hline
\end{tabular}

susceptible with respect to pod damage (> $30 \%$ pod damage) against $M$. vitrata in black gram.

\section{Screening of black gram genotypes against $M$. vitrata} during Kharif, 2019

The data presented in Table 2, reveals that the pod infestation by $M$. vitrata ranged from 6.67 to 26.67 per cent. Out of 15 black gram genotypes screened against $M$. vitrata minimum pod infestation of 6.67 per cent was recorded in KU-99-05 and followed by Azad Urd-1 and Shekhar-2 with 9.00 and10.33 per cent, respectively and were categorized as resistant (R). Whereas, nine genotypes viz., PU-19, PU6, Azad Urd-2, PU-40, PU-35, KU-96-7, Shekhar-1, KU-302 and PU-30 were observed with pod infestation of 13.33 , $14.00,14.67,16.00,16.67,17.33,19.67,20.33$ and 22.33 per cent, respectively and these genotypes were found moderately resistant (MR). Only three genotypes viz., Azad Urd-3 (25.33\%), KU-719 (26.00\%) and KU-88-9-1(26.67\%) were observed with more pod infestation and these genotypes were grouped as moderately susceptible (MS) against $M$. vitrata. Among all the 15 genotypes of black gram no genotype was found susceptible with respect to pod damage (> 30\% pod damage) against $M$. vitrata in black gram.

\section{Screening of black gram genotypes against $\boldsymbol{H}$. armigera} during Kharif, 2018

The 15 black gram genotypes were screened to check the resistance and susceptibility against $H$. armigera. The statistically analyzed data presented in Table 3 reveals that the pod infestation by $H$. armigera ranged from 6.33 to 26.67 per cent during Kharif, 2018. Among all the black gram genotypes minimum pod infestation of 6.33 per cent was recorded in Azad Urd-1 genotype and followed by KU-9905, Shekhar-2 and PU-6 with 7.00, 9.33 and 10.67 per cent, respectively and categorized as resistant $(R)$. Whereas, 10 genotypes viz., PU-19, PU-35, Azad Urd-2, KU-96-7, PU40, KU-302, Shekhar-1, PU-30, Azad Urd-3 and KU-719 were observed with pod infestation of 13.33, 15.67, 16.00, 18.67, 19.00, 20.67, 21.33, 22.00, 22.67 and 24.00 per cent, respectively and these genotypes were found moderately resistant (MR). Only one genotype viz., KU-88-9-1 was observed with maximum pod infestation and recorded as moderately susceptible (MS) with 26.67 per cent against $H$. armigera. Among all the 15 genotypes of black gram no genotype was found susceptible (> $30 \%$ pod damage) with respect to pod damage against $H$. armigera in black gram.

Screening of black gram genotypes against $\boldsymbol{H}$. armigera during Kharif, 2019

The data presented in Table 3 reveals that the $H$. armigera pod infestation in different genotypes ranged from 4.67 to 25.00 per cent during Kharif, 2019. Among all the black gram genotypes minimum pod infestation of 4.67 per cent was recorded in KU-99-05genotype and followed by Azad Urd-1, Shekhar-2, PU-6 and PU-19 with 6.00, 7.67, 9.00 and 10.67 per cent, respectively and categorized as resistant (R). 
Whereas, nine genotypes viz., Azad Urd-2, PU-35, KU-96-7, PU-40, KU-302, Shekhar-1, Azad Urd-3, PU-30 and KU-719 were observed with pod infestation of 13.67, 14.33, 16.00, $16.67,18.00,19.00,20.33,20.67$ and 22.33 per cent, respectively and these genotypes categorizes as moderately resistant (MR). Only one genotype viz., KU-88-9-1 was found moderately susceptible with 25.00 per cent pod infestation against $H$ armigera. Among all the 15 genotypes of black gram no genotype was found susceptible (> $30 \%$ pod damage) with respect to pod damage against $H$. armigera in black gram.

Almost similar procedures was adopted by Shivaraju (2008) who screened 22 germplasms of black gram against pod borers $(M$. vitrata and $H$. armigera ) and revealed that no genotype reacted as highly resistant, five genotypes reacted as resistant, six genotypes as moderately resistant,

Table 2: Screening of black gram genotypes against Maruca vitrata during Kharif, 2018, 2019 and Pooled.

\begin{tabular}{|c|c|c|c|c|c|c|}
\hline \multirow{2}{*}{ Genotypes } & \multicolumn{2}{|c|}{2018} & \multicolumn{2}{|c|}{2019} & \multicolumn{2}{|c|}{ Pooled } \\
\hline & Pod damage (\%) & Category & Pod damage (\%) & Category & Pod damage (\%) & Category \\
\hline Azad Urd - 1 & 10.33 (18.67) & $\mathrm{R}$ & $9.00(17.30)$ & $\mathrm{R}$ & 9.67 (18.08) & $\mathrm{R}$ \\
\hline Azad Urd - 2 & $16.33(23.80)$ & MR & 14.67 (22.42) & MR & $15.50(23.13)$ & MR \\
\hline Azad Urd - 3 & 26.67 (31.08) & MS & $25.33(30.21)$ & MS & $26.00(30.65)$ & MS \\
\hline Shekhar - 1 & $22.33(28.17)$ & MR & 19.67 (26.30) & MR & $21.00(27.25)$ & MR \\
\hline Shekhar - 2 & 13.67 (21.66) & MR & 10.33 (18.67) & $\mathrm{R}$ & $12.00(20.23)$ & $\mathrm{R}$ \\
\hline $\mathrm{KU}-96-7$ & $17.00(24.34)$ & MR & 17.33 (24.59) & MR & $17.17(24.47)$ & MR \\
\hline KU -99-05 & 8.67 (17.08) & $\mathrm{R}$ & $6.67(14.78)$ & $\mathrm{R}$ & 7.67 (15.99) & $\mathrm{R}$ \\
\hline KU - 719 & $27.33(31.50)$ & MS & $26.00(30.65)$ & MS & 26.67 (31.09) & MS \\
\hline KU - 88-9-1 & 28.67 (32.34) & MS & 26.67 (31.07) & MS & 27.67 (31.72) & MS \\
\hline KU - 302 & $21.00(27.24)$ & MR & $20.33(26.78)$ & MR & $20.67(27.04)$ & MR \\
\hline$P U-6$ & $14.67(22.47)$ & MR & $14.00(21.94)$ & MR & $14.33(22.21)$ & MR \\
\hline PU - 19 & $15.00(22.72)$ & MR & $13.33(21.36)$ & MR & 14.17 (22.09) & MR \\
\hline PU - 30 & $25.67(30.41)$ & MS & $22.33(28.14)$ & MR & $24.00(29.30)$ & MR \\
\hline PU - 35 & $17.00(24.28)$ & MR & 16.67 (24.05) & MR & $16.83(24.18)$ & MR \\
\hline PU - 40 & $19.33(26.04)$ & MR & $16.00(23.55)$ & MR & 17.67 (24.82) & MR \\
\hline $\mathrm{SDm}_{ \pm}$ & 1.18 & & 1.24 & & 0.92 & \\
\hline CD at $5 \%$ & 3.43 & & 3.58 & & 2.67 & \\
\hline $\mathrm{R}=$ Resistant & & & $=$ Moderately Resis & & MS = Moder & sceptible \\
\hline
\end{tabular}

Table 3: Screening of black gram genotypes against Helicoverpa armigera during Kharif, 2018, 2019 and Pooled.

\begin{tabular}{|c|c|c|c|c|c|c|}
\hline \multirow{2}{*}{ Genotypes } & \multicolumn{2}{|c|}{2018} & \multicolumn{2}{|c|}{2019} & \multicolumn{2}{|c|}{ Pooled } \\
\hline & Pod damage (\%) & Category & Pod damage (\%) & Category & Pod damage (\%) & Category \\
\hline Azad Urd - 1 & 6.33 (14.39) & $\mathrm{R}$ & $6.00(14.05)$ & $\mathrm{R}$ & $6.17(14.34)$ & $\mathrm{R}$ \\
\hline Azad Urd - 2 & $16.00(23.49)$ & MR & 13.67 (21.59) & MR & $14.83(22.62)$ & MR \\
\hline Azad Urd - 3 & 22.67 (28.41) & MR & $20.33(26.78)$ & MR & $21.50(27.60)$ & MR \\
\hline Shekhar - 1 & $21.33(27.47)$ & MR & $19.00(25.74)$ & MR & 20.17 (26.63) & MR \\
\hline Shekhar - 2 & $9.33(17.59)$ & $\mathrm{R}$ & 7.67 (15.93) & $\mathrm{R}$ & $8.50(16.78)$ & $\mathrm{R}$ \\
\hline KU - 96-7 & $18.67(25.56)$ & MR & $16.00(23.53)$ & MR & $17.33(24.60)$ & MR \\
\hline KU -99-05 & $7.00(15.18)$ & $\mathrm{R}$ & 4.67 (12.28) & $\mathrm{R}$ & $5.83(13.80)$ & $\mathrm{R}$ \\
\hline $\mathrm{KU}-719$ & 24.00 (29.29) & MR & $22.33(28.20)$ & MR & 23.17 (28.76) & MR \\
\hline KU - 88-9-1 & $26.67(31.06)$ & MS & $25.00(29.97)$ & MS & $25.83(30.53)$ & MS \\
\hline $\mathrm{KU}-302$ & 20.67 (26.98) & MR & $18.00(25.04)$ & MR & 19.33 (26.08) & MR \\
\hline$P U-6$ & 10.67 (18.89) & $\mathrm{R}$ & $9.00(17.30)$ & $\mathrm{R}$ & $9.83(18.17)$ & $\mathrm{R}$ \\
\hline PU - 19 & $13.33(21.31)$ & MR & 10.67 (18.98) & $\mathrm{R}$ & $12.00(20.27)$ & $\mathrm{R}$ \\
\hline$P U-30$ & $22.00(27.96)$ & MR & 20.67 (27.03) & MR & $21.33(27.51)$ & MR \\
\hline PU - 35 & $15.67(23.25)$ & MR & $14.33(22.21)$ & MR & $15.00(22.75)$ & MR \\
\hline$P U-40$ & $19.00(25.80)$ & MR & $16.67(24.06)$ & MR & $17.83(24.98)$ & MR \\
\hline $\mathrm{SDm}_{ \pm}$ & 1.27 & & 1.31 & & 0.82 & \\
\hline CD at $5 \%$ & 3.69 & & 3.79 & & 2.39 & \\
\hline
\end{tabular}

$\mathrm{R}=$ Resistant $\quad \mathrm{MR}=$ Moderately Resistant

Values in parentheses are arc sine transformed values. 
six genotypes as susceptible and five genotypes proved highly susceptible with respect of resistance to larval boring. Among genotypes screened, the least pod borer damage $(5.31 \%)$ was recorded in KU8-639 followed by KU8-640 $(7.54 \%)$ and the highest pod damage recorded in KU8-632 (63.27\%). Krishna et al. (2006) screened black gram genotypes against $M$. vitrata and $H$. armigera and revealed that five genotypes viz., LBG 762, LBG 726, LBG 747, LBG 744 and LBG 745 were found with minimum larval population and less damage. Mandal (2005) screened 18 cultivars of green gram for resistance to pod borer ( $M$. vitrata). The cultivars ML 5, ML 408 and RMG 266 were categorized as resistant ( $<5 \%$ pod damage). Whereas, cultivars $M L 131$, ML 505, RMG 275, Pusa 8971 and Pusa 8972 were moderately resistant $(5.1-10 \%$ pod damage). The cultivars PDM 219, RMG 175, RMG 202, Pusa 8974, Pusa Baisakhi and K851 were regarded as moderately susceptible (10.1$15 \%$ pod damage). While, the remaining entries viz., PDM 216, ML 537, PDM 86-199 and WBM 202 were susceptible (>15\% pod damage). Soundararajan and Chitra (2014) screened 51 black gram germplasm for resistance against pod borer complex and reported thatnine germplasms viz., CBG 08-009, CBG 08-014, CBG 08-040, CBG 08-045, CBG 08-057, PLU 102, 5-16-7, PLS 364/42 and KU 301 were scored as moderately resistant in both kharif and rabi seasons. Naik and Mallapur (2019) reported that the black gram genotypes viz., LBG-685 (8.25\%), WBU-108 (9.25\%), COBG-653 (9.35\%), VBN-05 (9.30\%) and PU-31(10.10\%) which are tolerant may be utilized in resistance breeding programmes against $M$. vitrata and may be recommended for their cultivation in the endemic areas. The findings of Kumar and Singh (2014) also support present findings who reported that the minimum infestation was recorded in black gram genotypes viz., KUG-503 and UH-08- 05, followed by COBG-10-5 and VBG10-024. Sandhya Rani et al. (2012) evaluated 12 greengram entries during rabi and reported that, Maruca pod borer damage ranged from 11.6 (MGG 364 ) to $25.7 \%$ (MGG 356) and the entries, MGG 364 (11.6\%), MGG 365 (14.3\%) and MGG 363 (14.6\%) were found to be tolerant. Sandhya Rani et al. (2014) studied the varietal preference of spotted pod borer, $M$. vitrata to 110 different green gram genotypes including 10 released varieties and reported that five genotypes, KM-9-128 (3.5\%), KM-9-136 (5.8\%), RMG-492 (8.34\%), LGG-527 (9.5\%) and LGG-538 $(10.0 \%)$ were found as tolerant. Soundararajan and Chitra (2017) carried out field screening of 44 mungbean germplasm during kharif and rabifor resistance to pod borer complex and reported that four germplasm viz., KM 2-B, NPM 3-1, VGG 90 and VGG 04-016 were grouped as moderately resistant in both seasons. Singh and Singh (2019) evaluated 20 genotypes of green gram for their susceptibility levels against the spotted pod borer, $M$. vitrata and reported that the genotype PM-5 (7.72 q/ha) closely followed by IPM 306-1 (6.96 q/ha) and HUM-16 (6.58 q/ha) gave the maximum yield. Singh et al. (2018) evaluated 20 genotypes of green gram and reported that the genotype
Pant M6 was found most tolerant to spotted pod borer. The above reports support the present findings.

\section{CONCLUSION}

It can be concluded that the black gram genotypes viz., KU99-05 and Azad Urd-1 were identified as resistant against M. vitrata. Whereas, genotypes KU-99-05, Azad Urd-1, Shekhar-2 and PU-6 were found resistant against $H$. armigera. These findings certainly would go a long way in developing desirable black gram genotypes resistant to pod borers ( $M$. vitrata and $H$. armigera) eventually in providing most efficient and economic control strategy to the black gram growers.

\section{ACKNOWLEDGEMENT}

The author expresses thankfulness to the Department of Entomology, SVPUA and T, Meerut for their precious suggestions untiring help and moral support throughout this research work.

\section{REFERENCES}

Anonymous, (2018). Ministry of Agriculture and Farmers Welfare, Department of Agriculture, Cooperation and Farmers Welfare, Krishi Bhavan, New Delhi.

Anonymous, (2018a). Ministry of Agriculture and Farmers Welfare, Govt. of India.www.indiastat.com.

Kantar, F., Hafeez, B.G., Shivkumar, S.P., Sundaram, N.A., Tajera, P. (2007). Chickpea; Rhizobium management and nitrogen fixation. In: Chickpea Breeding and Management. pp. 179-192.

Krishna, Y., Koteswara Rao, Y., Rao, R.S., Rajasekhar, P., Srinivasa Rao, V. (2006). Screening for resistance against spotted pod borer, Maruca vitrata (Geyer) and Helicoverpa armigera (Hubner) in blackgram. Journal of Entomological Research. 30: 35-37.

Kumar, M. and Singh, P.S. (2014). Screening of black gram genotypes against major insect pests. Indian Journal of Entomology. 76: 84-86.

Mandal, S.M.A. (2005). Field screening of greengram varieties against pod borers. Environmental Ecology. 23: 381.

Naik, M.G. and Mallapur, C.P. (2019). Field screening of blackgram genotypes against spotted pod borer, Maruca vitrata (Geyer). Journal of Entomology and Zoology Studies. 7: 631-634.

Nene, Y.L. (2006). Indian pulses through the millennia. Asian Agrihistory. 10: 179-202.

Reddy, C.N. (1998). Pest complex and their sucession on pigeonpea variety. Indian Journal of Entomology. 60: 334-338.

Sandhya Rani, C., Eswari, K.B. and Sudarshanam, A. (2012). Reaction of greengram (Vigna radiata L.) OVT entries against major insect pests in rabi season. The Andhra Agricultural Journal. 59: 87-92.

Sandhya Rani, C., Ramachandra Rao, G., Chalam, M.S.V., Anil Kumar, P. and Srinivasa Rao, V. (2014). Field Screening of greengram genotypes against Maruca vitrata in summer. Journal of Agriculture and Crop Science. 1: 18-25. 
Shivaraju, C. (2008). Pest complex of black gram, [Vigna mungo (L.)] with special reference to pod borers and their management. M.Sc. Thesis, GKVK, University of Agricultural Sciences, Bangalore, Karnataka, India.

Singh, S., Singh, P.S., Meena, R.S., Saxena, R.P.N., Singh, S.K. (2018). Screening of certain greengram [Vigna radiata (L.)Wilczek] genotypes for resistance against pod bugs and spotted pod borer. Journal of Experimental Zoology India. 21: 133-136

Singh, S.K. and Singh, P.S. (2019). Screening of green gram genotypes against spotted pod borer Maruca vitrata (F.). Indian Journal of Entomology. 81: 740-743.
Soundararajan, R.P. and Chitra, N. (2014). Field screening of black gram, (Vigna mungo L.) germplasm for resistance against pod borer complex. Indian Journal of Entomology. 76: 142-148.

Soundararajan, R.P. and Chitra, N. (2017). Field evaluation of mung bean (Vigna radiata L.) germplasm for resistance against pod borer complex. Legume Research. 40: 768-772.

Tiwari, A.K. and Shivhare, A.K. (2016). Pulses in India: Retrospect and Prospectus. Published by Director, Govt. of India, Ministry of Agri. and Farmers Welfare, Directorate of Pulses Development, Vindhyachal Bhavan, Bhopal (M.P). 